\title{
Pelatihan Aspek Marketing Mix Pada Pelaku Usaha Bonggolan Di Desa Pengulu Kecamatan Sidayu Kabupaten Gresik
}

\author{
Ferry Hariawan ${ }^{1}$, Nashrudin Latif ${ }^{2}$, Christina Menuk Sri Handayani ${ }^{3}$, \\ Evita Purnaningrum ${ }^{4}$ \\ ${ }^{1234}$ Program Studi Manajemen, Fakultas Ekonomi \\ Universitas PGRI Adi Buana Surabaya \\ E-mail : ferry@unipasby.ac.id
}

\begin{abstract}
ABSTRAK
Lapangan usaha pada sektor pertanian, perikanan dan industri pengolahan di Desa Pengulu sangat beragam. Kondisi tersebut merangsang munculnya UMKM yang saling terkait dengan potensi lokal yang dimiliki Desa Pengulu dengan wilayah desa lainnya di Kecamatan Sidayu, Kabupaten Gresik. Permasalahan yang terjadi menunjukkan kurang berkembangnya produk Bonggolan dari sisi pemasaran dikarenakan minimnya pendidikan dalam mengembangkan potensi lokal yang ada. Potensi UMKM membutuhkan penguatan melalui pengabdian masyarakat dengan basis pemberian edukasi tentang marketing mix $7 P$ untuk mengembangkan produk Bonggolan. Peningkatan dan perbaikan atas kendala yang dihadapi dengan keterkaitan antar komponen marketing mix $7 P$ untuk meningkatkan penjualan dan kepuasan konsumen. Dampak yang dihasilkan dari pengabdian masyarakat menunjukkan peningkatan kesadaran masyarakat desa dalam upayanya untuk pengembangan produk, peningkatan kesejahteraan warga dan perekonomian desa Pengulu.
\end{abstract}

Kata kunci : Potensi Desa, UMKM, Bauran Pemasaran, Produk Bonggolan.

\begin{abstract}
Business fields in the agriculture, fishery and processing industries in Pengulu Village are very diverse. These conditions stimulated the emergence of MSMEs that are interrelated with the local potential of Pengulu Village and other village areas in Sidayu District, Gresik Regency. The problems that occur indicate the underdevelopment of Bonggolan's products in terms of marketing due to the lack of education in developing existing local potential. The potential of MSME requires strengthening through community service on the basis of providing education about the 7P marketing mix to develop Bonggolan products. Improvements and improvements to the obstacles faced by the linkages between the components of the 7P marketing mix to increase sales and customer satisfaction. The impact resulting from community service shows increased awareness of the village community in its efforts to develop products, improve the welfare of residents and the economy of the village of Pengulu.
\end{abstract}

Keywords: Village Potential, SMEs, Marketing Mix, Bonggolan Products. 


\section{PENDAHULUAN}

Peran penting dan strategis dimiliki oleh Usaha Mikro, Kecil dan Menengah (UMKM) dalam pembangunan ekonomi nasional. Peran pentingnya dilihat dari pertumbuhan ekonomi, penyerapan tenaga kerja dan pendistribusian hasil-hasil pembangunan. Bukti nyata UMKM diwujudkan juga dengan tidak terpengaruhnya terhadap krisis moneter. Krisis yang melanda Indonesia pada periode tahun 1997-1998, menunjukkan kemampuan UMKM bertahan hidup.

Pasca krisis ekonomi tahun 1997-1998, berdasarkan Data Badan Pusat Statistik, jumlah UMKM justru meningkat dan mampu menyerap 85juta sampai dengan 107juta tenaga kerja hingga tahun 2012 dengan banyaknya pengusaha di Indonesia sejumlah 56.539.560 unit. Dari jumlah sebanyak itu, 99.99\% atau sebanyak 56.534.502 unit adalah UMKM, sedangkan sisanya dimiliki usaha skala besar sekitar $0,01 \%$ atau sebanyak 5.968 unit. Data tersebut menunjukkan bisnis skala UMKM sebagai pasar potensial untuk diberi porsi pengembangan yang lebih besar. Perhatian pemerintah dan legislatif ditunjukkan dengan adanya Undang-Undang Nomor 20 Tahun 2008 tentang usaha mikro kecil dan menengah. Peraturan yang menjadi payung hukum gerak UMKM yang semakin luas.

Bisnis UMKM mampu menyumbang Produk Domestik Bruto (PDB) sebesar 60\% dan menyediakan lapangan pekerjaan (Kementerian Koperasi dan UMKM, 2019). Pada kurun waktu tahun 2011 sampai 2012 menunjukkan peningkatan pada UMKM dan penurunan pada jenis usaha besar. Usaha besar pada tahun 2011 menjadi 41,95\% dan tahun 2012 mencapai 41,95\%, sehingga ada penurunan sekitar 1,03\%. Sedangkan UMKM mengalami perubahan pada usaha menengah di tahun 2011 mencapai 13,46\% dan tahun 2012 sebesar 13,59\%, sehingga ada peningkatan sebesar 0,13\%. Untuk perubahan usaha kecil pada tahun 2011 mencapai 9,94\% dan tahun 2012 sebesar 9,68\%, artinya menurun sekitar $0,26 \%$. Peningkatan yang signifikan justru terjadi pada usaha mikro dimana tahun 2011 mencapai 34,64\% dan tahun 2012 meraih 38,81\%, sehingga terdapat kenaikan sebesar $4,17 \%$.

Total kontribusi UMKM terhadap PDB Nasional adalah akumulasi dari semua sektor ekonomi dari UMKM. Konsep ISIC (International Standard Classification of All Economic Activities) yang direvisi tahun 1968, menjadi panduan dalam klasifikasi jenis kegiatan ekonomi. Klasifikasi tersebut bertujuan untuk memudahkan perbandingan tingkat aktivitas ekonomi antar berbagai kegiatan. Penggolongan utama sektor ekonomi terbagi sembilan area (Kementerian Koperasi dan UMKM, 2020) yaitu 1), Pertanian, peternakan, kehutanan dan perikanan, 2), Pertambangan dan penggalian, 3), Industri pengolahan, 4), Listrik, gas dan air bersih, 5), Bangunan, 6), Perdagangan, hotel dan restoran, 7), Pengangkutan dan komunikasi, 8), Keuangan, persewaan dan jasa perusahaan, dan 9), Jasa-jasa. Jumlah perkembangan UMKM berdasar sektor ekonomi pada tahun 2011 (Kementerian Koperasi dan UMKM, 2020) memiliki proporsi dari unit terkecil sampai terbesar adalah sektor (1) 0,03\% pada listrik, gas dan air bersih, (2) 0,53\% pada pertambangan dan penggalian, (3) 1,57\% pada bangunan, (4) 2,37\% pada keuangan, persewaan dan jasa perusahaan, (5) 4,52\% pada jasa-jasa, (6) 6,41\% pada industri pengolahan, (7) 6,88\% pada pengangkutan dan komunikasi, 28,83\% pada perdagangan, 
hotel dan restoran, dan peringkat teratas sebanyak $48,85 \%$ pada pertanian, peternakan, kehutanan dan perikanan.

\section{Potensi Industri Pengolahan}

Sektor industri pengolahan merupakan salahsatu dari kegiatan ekonomi. Kegiatan ekonomi yang mengolah mulai dari bahan dasar menjadi barang yang memiliki nilai tinggi dan sifatnya lebih dekat kepada pemakai akhir, termasuk kegiatan rancang bangun dan perekayasaan industri. Badan Statistik kabupaten Gresik (Statistik, 2020) menunjukkan distribusi PDRB lapangan usaha industri pengolahan khususnya industri makanan dan minuman pada tahun 2013-2017 yaitu tahun 2013 (17,74\%), tahun 2014 $(17,68 \%)$, tahun $2015(19,47 \%)$, tahun $2016(21,89)$ dan tahun $2017(23,13 \%)$, artinya ada penurunan sekitar $0,06 \%$ di tahun 2014 dan kenaikan sekitar $2 \%$ pada kurun waktu 2015-2017. Potensi tersebut ditopang dengan adanya distribusi PDRB lapangan usaha perikanan pada tahun 2013-2017 dimana tahun 2013 (53,85\%), 2014 (55,62\%), 2015 $(57,12 \%), 2016(58,63 \%)$ dan 2017 (59,90\%), artinya tiap tahun ada pertumbuhan sekitar $1,5 \%$.

Kedua lapangan usaha yaitu industri pengolahan dan perikanan saling terkait dikarenakan beberapa produk unggulan dari industri pengolahan mengambil bahan baku dari perikanan. Dimana potensi keduanya tersebar dengan baik di Kecamatan Sidayu yang memiliki 21 desa (Gresikkab.go.id, 2020). Masing-masing desa memiliki produk unggulan dari industri olahan berbahan umum, industri olahan berbahan perikanan dan lapangan usaha dari pertanian/perikanan. Industri olahan berbahan baku umum tersebar pada 11 desa yaitu kripik buah dan tempe (Desa Sukorejo), manisan tomat (Desa Lasem), songkok/kopyah (Desa Ngawen), aneka roti (Desa Asempapak), Ape'e, susu kedelai, minuman temulawak, krupuk ikan dan tempe (Desa Sidomulyo), krupuk goreng pasir, pandai besi dan gerabah (Desa Bunderan), tas (Desa Kauman), susu kedelai (Desa Golokan), kripik uyel, tempat pot (Desa Sambipondok), dan tahu dan kare ayam (Desa Wadeng). Terdapat 6 desa yang memiliki industri pengolahan berbahan perikanan yaitu krupuk, bonggolan, minuman temulawak dan minuman kedelai (Desa Pengulu), krupuk ikan dan bonggolan (Desa Srowo), krupuk ikan (Desa Randu Boto), krupuk ikan dan kerang (Desa Mojoasem), otak-otak bandeng (Desa Mriyunan), kerajinan kerang, krupuk ikan dan perikanan (Desa Purwodadi), dan krupuk ikan (Desa Sedagaran). Sedangkan dari lapangan usaha pertanian dan perikanan terdapat 3 desa yaitu perikanan dan pertanian (Desa Raci Kulon), cat tembok, batu onik, batu bata ringan, perikanan (Desa Kertosono), produk pertanian (Desa Raci Tengah) dan mangga (Desa Gedangan).

\section{Urgensi Bauran Pemasaran 7P}

Data-data potensi UMKM menunjukkan kontribusi positif sebagai tulang punggung perekonomian daerah, semua sektor tersebar secara geografis di beberapa wilayah desa dengan memberikan multiplier effect yang tinggi, sebagai media menciptakan wirausaha baru dan minimnya ketergantungan terhadap komponen impor. Namun capaian peran strategis tersebut masih menemui kendala yang sering muncul dalam UMKM (Bank 
Indonesia, 2015) baik internal (modal, sumber daya manusia, hukum dan akuntabilitas) dan ekternal (iklim usaha masih belum kondusif, infrastruktur, akses). Kendala bisnis industri pengolahan seringkali ditemukan pada sisi lokasi usaha, perizinan usaha, tata kelola pengelolahan limbah, standardisasi produk, sifat produk (customized atau tidak), status pada kepemilikan lokasi usaha, tecknologi dan peralatan yang dipakai, potensi sumber daya manusia, orientasi usaha dan tingkat persaingan (competitor).

Kegiatan bisnis UMKM menyediakan produk yang kreatif, inovatif dan menarik untuk memenuhi kebutuhan dan keinginan konsumen sehingga membutuhkan peran pemasaran. Pemasaran sebagai media perantara antara produsen dan konsumen dipilih sebagai salahsatu strategi bersaing dan bertahan hidup pada usaha sejenis (Adhaghassani \& Purwanti, 2016). Bauran pemasaran atau marketing mix menjadi salahsatu alat manajemen untuk mencapai tujuan pemasaran yang digunakan oleh perusahaan (Kotler\&Amstrong, 2012). Dimana marketing mix adalah kendali perlengkapan pemasaran yang dipadukan perusahaan untuk menghasilkan respon dari target pasar, yang terdiri dari product, price, place and promotion (4P). Mengingat perkembangan pemasaran yang berorientasi pada pelanggan maka ditambahkan unsur 3P yaitu people, process and physical evidence (Jain, 2013). Komponen product yang baik didasarkan atas pemberian produk dan/jasa yang nyata, berdasarkan kebutuhan konsumen dan memberikan konsumen atas pengalaman tertentu (Kotler\&Amstrong, 2012). Aspek price mencerminkan kesesuaian antara keinginan konsumen dengan jumlah uang yang telah dibayarkan (Lovelock, et al, 2011). Unsur place dikatakan baik jika ada kemudahan akses bagi pelanggan potensial dan memberikan kesesuaian hubungan timbal balik (Solomon, et al, 2013). Lebih lanjut Lovelock, C., Wirtz, J., \& Mussury, J. (2011) menjelaskan bauran pemasaran yang lain yaitu promotion sebagai sarana komunikasi yang efektif dalam memberikan informasi bagi target pelanggan dan mendorongnya untuk mengambil keputusan pada waktu tertentu, keahlian teknik dalam pekerjaan dan memiliki sikap positif menjadi keunggulan kompetitif bagi people, process adalah upaya pelayanan kepada pelanggan secara efektif, cepat dan teratur tanpa memicu keluhan konsumen, sedangkan physical evidence menunjukkan kepercayaan konsumen pada perusahaan seperti adanya brosur, penampilan karyawan yang rapi dan sopan, dekorasi internal/ekstenal yang menarik.

\section{METODE PELAKSANAAN}

Potensi industri pengolahan Kecamatan Sidayu sangat beragam sehingga dalam pengabdian masyarakat ini membatasi pada strategi bauran pemasaran industri pengolahan produk Bonggolan di Desa Pengulu. Pembatasan ini dilakukan berdasarkan pertimbangan upaya pengembangan kegiatan ekonomi secara spesifik, memperluas pangsa pemasaran produk Bonggolan melalui media online dimana pemasaran melalui Instragam masih minim yaitu sebanyak 57 pemilik akun Bonggolan dan memperbanyak upaya google search tentang produk Bonggolan. Maka dalam kegiatan pengabdian ini dilakukan dengan cara memberikan edukasi secara deskriptif untuk menjelaskan bagaimana produk Bonggolan ditingkatkan melalui strategi marketing mix $7 P$. 
Pendidikan masyarakat ini diselenggarakan dengan konsep memberi penyuluhan untuk memberi pemahaman dan penyadaran secara massif bagi masyarakat yang membutuhkan pengembangan aktivitas ekonomi khususnya produk Bonggolan.

Kegiatan ini dilakukan secara bersama oleh tim pengabdian masyarakat Fakultas Ekonomi Universitas Adi Buana Surabaya. Sasaran target peserta adalah masyarakat Desa Pengulu dimana kegiatan tersebut dijalankan berdasarkan jadwal yang telah disesuaikan waktunya oleh masyarakat. Fleksibilitas ini dilakukan mengingat kesibukan peserta dalam beraktivitas sehingga tidak mengganggu sepenuhnya dan kegiatan dapat terselenggara dengan baik.

\section{HASIL DAN PEMBAHASAN}

Desa Pengulu secara geografis terletak di wilayah kecamatan Sidayu, Kabupaten Gresik. Beberapa wilayah kecamatan Sidayu diisi area pertanian dan perikanan, sehingga pada daerah perikanan memiliki potensi menghasilkan produk-produk perikanan yang berkualitas seperti udang dan bandeng dengan bentuk turunan produk lainnya seperti krupuk ikan, otak-otak bandeng dan bonggolan. Kondisi tersebut menunjukkan potensi yang menarik sekaligus terdapat tantangan didalamnya. Dimana kondisi masyarakat Desa Pengulu masih membutuhkan penguatan di bidang (1) pengetahuan dan ketrampilan (skill) dalam menguasai teknologi, (2) produktivitas masyarakat dan (3) terbatasnya sarana dan prasarana. Hal ini berakibat pada rendahnya kesejahteraan masyarakat dan partisipasinya dalam pembangunan perekonomian desa.

Edukasi bauran pemasaran diberikan untuk memberdayakan masyarakat dalam pengembangan produk khususnya Bonggolan. Dimana aspek product, Bonggolan belum mampu menarik lebih banyak lagi konsumen mengingat bentuk tampilan/varian yang kurang kekinian, sertifikasi kesehatan dan kurang memberikan value kepada konsumen. Aspek place, masih menunjukkan lokasi yang tersebar di perumahan masyarakat, artinya belum menjadi destinasi kuliner yang menarik. Sedangkan promotion, belum maksimal melalui media sosial atau pameran kuliner yang diselenggarakan pemerintah setempat. People menjadi komponen penting dalam pengembangan produk Bonggolan dikarenakan orang yang secara langsung berinteraksi dengan konsumen dengan modal kepribadian yang menarik. Sedangkan process terkait dengan people sebagai pengendali masih perlu membutukan penyadaran pentingnya melayani konsumen secara sempurna. Sehingga langkah training dibutuhkan untuk lebih mengoptimalkan peran people. Dalam physical evidence atau bukti fisik terlihat masih terbatas di area perkampungan sehingga belum menjangkau pasar yang lebih luas.

\section{DAMPAK DAN MANFAAT KEGIATAN}

Strategi penguatan bauran pemasaran dilakukan untuk memberikan pengetahuan dan motivasi kepada masyarakat Desa Pengulu dalam mengembangkan produk Bonggolan. Produk lokal ini diharapkan menjadi produk unggulan desa sebagai langkah differensiasi dan penguatan jejaring ekonomi daerah setempat. Kesadaran untuk andil dalam pemberdayaan masyarakat diwujudkan dengan menerapkan strategi marketing mix $7 P$ 
untuk memenuhi kebutuhan dan keinginan konsumen. Penerapan tujuh komponen didalamnya baik itu product, price, place, promotion, people, process and physical evidence dapat menguatkan produk lokal yang mampu membantu perekonomian masyarakat desa Pengulu dan menciptakan pasar yang lebih besar.

\section{SIMPULAN}

Strategi marketing mix $7 P$ produk Bonggolan sebagai representasi pengembangan UMKM yang dibutuhkan masyarakat desa Pengulu. Pendekatan alat manajemen dalam menciptakan laba dan memenuhi kebutuhan/keinginan konsumen dipakai sebagai upaya untuk memberdayakan partisipasi masyarakat dalam membangun perekenomian desa. Partisipasi masyarakat dalam mengenali potensi lokal dan mengembangkannya menjadi media untuk peningkatan pengetahuan dan ketrampilan sekaligus peningkatan kesejahteraan masyarakat desa.

\section{UCAPAN TERIMA KASIH}

Ucapan terima kasih kepada pihak-pihak yang berperan dalam membantu kelancaran kegiatan ini. Ucapan terima kasih disampaikan kepada Universitas PGRI Adi Buana Surabaya melalui Lembaga Pengabdian Pada Masyarakat (LPPM), Fakultas Ekonomi Universitas PGRI Adi Buana Surabaya, Kepala Desa Pengulu kecamatan Sidayu, Kabupaten Gresik beserta para perangkat Desa, Pemerintah Kabupaten Gresik, dan segala pihak yang sudah membantu proses jalannya kegiatan ini.

\section{DAFTAR PUSTAKA}

Adhaghassani, Sefti Fakhriyyan dan Purwanti, Sutriyati, (2016), Strategi Bauran Pemasaran 7P (product, price,place, promotion, people, process, physical evidence) di cherryka bakery. Jurnal Pendidikan Teknik Boga.

Bank Indonesia, Profil Bisnis UMKM. Diakses dari https://www.bi.go.id/id/umkm/penelitian/nasional/kajian/Pages/Profil-BisnisUMKM.aspx, pada tanggal 9 April 2019

Jain, M. K. (2013). Asian Journal of Multidiciplinary Studies. An Analysis of Marketing Mix : 7 P or More, 23-28

Kabupaten Gresik, Profil Desa. Diakses dari https://gresikkab.go.id/profil/desa_di_kecamatan_sidayu, pada tanggal 9 April 2019

Kabupaten Gresik, Data Statistik. Diakses dari https://statistik.gresikkab.go.id/datapotensi, pada tanggal 9 April 2019

Kementerian UMKM. Statistik Usaha Mikro, Kecil dan Menengah Tahun 2010 - 2011. Diakses dari www.depkop.go.id pada tanggal 9 April 2019

Kotler, P., \& Amstrong, G. (2012). Principles of Marketing 14th Edition. London: Pearson Education Ltd

Lovelock, C., Wirtz, J., \& Mussury, J. (2011). Pemasaran Jasa : Manusia, Teknologi,Strategi - Perspektif Indonesia, Jilid 1 Edisi Ketujuh. Jakarta: Penerbit Erlangga.

Solomon, M., Hughes, A., Chitty, B., Marshall, G., \& Stuart, E. (2013). Marketing : Real People, Real Choice $7^{\text {th }}$ Edition. Australia: Pearson Higher Education. 